Martins, 2018

Volume 3 Issue 3, pp.1384-1403

Date of Publication: $5^{\text {th }}$ February 2018

DOI-https://dx.doi.org/10.20319/pijss.2018.33.13841403

This paper can be cited as: Martins, M. (2018). European Union And International Relations: Old

Times, New Times?. People: International Journal of Social Sciences, 3(3), 1384-1403.

\title{
EUROPEAN UNION AND INTERNATIONAL RELATIONS: OLD TIMES, NEW TIMES?
}

\author{
Marco António Batista Martins \\ Assistant Professor, Evora University, CICP (FCT), Évora, Portugal
}

mabm@uevora.pt

\begin{abstract}
Today, Europe is living a new decisive time as it has been in its past after World War II, in search of unity in diversity in the name of a peace project to safeguard future. If, on the one hand, Europe expresses aspirations for profound changes in its external environment, in the domestic context, it ends up colliding with aspects linked to sovereignty and human rights; on the other hand, in European foreign policy, the model reveals the search to legitimize its action. Precisely, the objective and the motivation of this study seek, through the qualitative methodology in Political Science, to analyse and understand the current context of the European Union in the international system. In fact, it is identified that this new hierarchy of powers, in the reaffirmation of the Westphalian system, where economic power comes, is bound to consolidate the democratic development between the old and new times of international relations in the destiny of Europe. From the results obtained during the analysis, in order to face again the unpredictability of the world scenario, it is a reality that Europe must promote the re-encounter of an alternative role, in other words, to assume its initial project of European edification in the name of equality of circumstances and rights of its affirmation in the global arena.
\end{abstract}

\section{Keywords}

European Union, World Order, Conflicts, Power 


\section{Introduction}

The fall of the Berlin Wall only meant postponing the unlikely future that came to pass a few decades later, in the construction by governmental decision of the separation of peoples in a kind of double function, on the one hand, to prevent the entrance of the undesirable and, on the other hand side, to a certain extent hinder the exit of those who are already inside. Access to European territory has become, for reasons of greater danger, not only because of the fight against terrorism, referring here not to increased vigilance in the name of protecting its own, but above all, by highlighting a problem of amplitude. This drama of the search for a home, a sort of Promised Land, brings to light the public debate that at the heart of the question is not the lack or the absence of habitable space, but a problem of character and the political spectrum. in view of the fact that a passport with the right to a visa was not at all necessary until a very short time ago, given the same, as it is presently perceived, a 20th century invention.

However, there is a growing conflict between the universality of human rights and the sovereign control of the territory, thus continuing the spirit of the Westphalian system (1648), denoting that the human community is divided by about 200 states with border, flag, and in some cases, estimated 50 borders surrounded by walls.

According to data from the World Bank for 2016, it is estimated that 247 million human beings are international migrants, although statistically representing a tiny percentage of $3.4 \%$ of the world population, however, evidence of global international mobility seeking a right to a place in the world, and has become a patent and dramatic reality. Let us note that in 5 years at European borders 22394 people have died who precisely wanted only to find a better place, escaping the horrors of wars, the bloody conflicts that have ravaged the world, reaping the lives of the most violent of children, men and women.

Recalling Thomas Piketty in his book Capital in the 21st Century (2014), it becomes interesting to denote the inexistence of a world empire, giving way to a world economy where gradually the statistical percentage of inequality is gradually increased not because of the inquisitorial finger of concentration but rather by those who continue to be regarded as the dumb peoples of the world, in the sense of Adriano Moreira, of the poorest and, above all, of these newly migrants whose majority ends up in corpses on Greek tourist beaches or floats in the waters of the Mediterranean . 
Thus, this new disorder in the world order that has gradually been raging and deconstructing the great geopolitical and humanitarian agreements on a global scale, presents the result of decades of policies that are described as "suicides." Otherwise, we proceed to the deconstruction of the achievements that were considered, in an era after World War II, definitive and representatives of single freedom for the human being. The ultimate freedom is wealth in the name of maximum benefit converting states, as actors of international relations, par excellence, serving large corporations in imposing their borders with their flag.

In fact, the right of every human being is based on obtaining a place in the world, and for this reason, this blue planet observed from the universe is tiny as a crystalline grain of sand is not for sale or looking for of an owner to own it, taking into account that it does not have singular property. According to this logic, the sphere belongs to the whole; because the whole is the sum of the parts, in other words, a common good of humanity, as the philosopher, António Campillo of the University of Murcia says in his work No man's land. How to think about the global society (2015) because as appointed by Selim (2017), we seek to live in harmony and promote the construction of a better world where everyone can stop their place and the right to human dignity, regardless of their culture and origin.

\section{Methodological and Theoretical Framework}

In the methodological framework of Political Science, specifically International Relations, we try to interpret and try to understand the reality surrounding the context of the European Union in its adaptation and capacity to respond to new threats, conjectural dynamics to ensure the possibility of development in the progressive operation of its strategic intervention capabilities in a pivotal role of Europe.

Therefore, as a hypothesis for the present analysis, from the perspective of the qualitative methodology of International Relations, we ask the following question, how will the European Union position itself in international relations, by adapting its foreign, defence and security policies? And how will be able to achieve in an increasingly uncertain world?

It is undeniable, the change of time, however, there is a management of mobility, from individuals, having them under two designations, on the one hand, those who invade a territory and die before, in the name of a dream of peace in them, on the other hand, investors with the right to a passport according to the investment capacity in a particular country. 
In fact, the problem is not subordinated to the acceptance of the other, the foreigner, but the inequality of the criterion of approval of the same according to what they have financially and whose project they intend to materialize. This position has given rise to the complicity between neoliberalism and neofascism because both end up creating the conditions for calling into question the political desideratum, for example, of the European Union, on the basis that each member state only stands for and individually assumes the 1 st place.

Therefore, we are plunged into a time of unknown path, perhaps because of the fact, regardless of the degree of uncertainty, where for example the newly elected President Trump has some respect/preference for his counterpart, Russian autocrat Vladimir Putin, and his opponent is applied. We live an apparent order in disorder where it has never been so necessary to rediscover a new balance of power in the present international order.

In Richard Haass's view (2017), taking into account all these recent changes in the international environment, from the United States, BRICS to the EU and Russia, a new redesign of the configuration of global equilibrium is generated, namely because it cannot be considered that only respect for sovereignty and its complementarity in the balance of powers system will respond to this operational model. Thus, Haass argues that one life in a world order 2.0 resulting from more than four hundred years under the Peace of Westphalia. It should be emphasized that the world order 1.0 consisted of the one that was based on the protection and the prerogatives of the states, being thus inadequate to the current times, as a consequence of the increasing interdependence. Practically, nothing is local, everything went on a global scale, from tourism to infectious diseases, in addition to that any internal conflict is likely to become internationally as well stresses Adriano Moreira (2016).

Nevertheless, it is not only a question of guaranteeing sovereignty; on the contrary, it is evident that each state is imperative to respond to the obligations of others; here, the concept of obligation of sovereignty is introduced as a counterpoint to the responsibility of sovereignty to act in an interdependent world, involving major powers such as China, France, Germany, India, Japan, Russia and the United Kingdom, in addition to the role that the EU, the G20 or the United Nations can play.

In this world order 2.0, consultations and conversations among others on global health, climate change and cyberspace or on prevention to prevent nuclear and arms proliferation will be indispensable in order to obtain the necessary support in order to avoid decontrol and violence. 
The existence of shared problems and responsibilities in this Order 2.0 reveals a central component of behavioural compromise in relation to the power of the major powers, the United States, Russia and the EU, regarding the equation of survival by mutual interest and the guarantee of the principle of common security. This theoretical approach from the perspective of Buzan and Lawson (2015) leads to assume in the national security agenda of each power, intervene in the name of security with and no longer security against, with common threats to climate change, the cyberspace and all of its surrounding hackers to cyberwar, the proliferation of weapons of mass destruction, space and, above all, the global economy.

Indeed, for Buzan and Lawson (2015), in this way of associating power as a result of this reality, it is eluded to the emergence of new actors in international relations, replacing the traditional Western domain, by guaranteeing the affirmation of new forms of organization, of the emergence of ideas that instigated the manifestation of other social realities.

From this perspective, the EU, according to Gariup (2009) considers the European Security and Defence Policy as a system of inclusion and response to international crises and/or conflicts without undermining the NATO, but working complementarily, is endowed with the capacity to face this new world order that Haass introduces as 2.0.

\section{BRICS and International Relations: from realities to transformations}

\subsection{The Emergence of New Actors}

The insertion of the BRICS in this 21st century expresses the testimony of a time of apparent change, where the established powers, the United States and the EU, continue to play a fundamental role in the reconfiguration of international relations. The emergence of new actors induces ambition and exalts the attempt to change from geopolitics to the global economy in a world of marked contrasts to increasingly appeal to a paradigm shift or a gradual transition to another system where exercise of global leadership or governance beyond American influence in politics and international relations, bearing in mind that the problems that humanity faces on its planet require solutions and initiatives that start from the whole in the promotion of multilateral cooperation.

According to Armijo (2007), in the field of International Relations Theory, we apply, in the pretension of finding an explanation on the form of coalition employed by the BRICS (Brazil, Russia, India, China and South Africa), the realistic paradigm regarding the behaviour 
emanated in the international arena by this group. Firstly, it is important to identify the relative material capacities of one or all of these countries if they are sufficiently significant and, on the other hand, in the near future, to consider them as major global powers capable of rivalling the United States.

In fact, the BRICS intend to assume this international scene position, even though domestically they face problems of the greatest dimension in terms of poverty, health, social inequalities, human rights and judicial. In order to contribute to the transition or rebalancing of the international system as an alternative to US hegemony, it is difficult for the BRICS to impose their will or to replace this European Union, even in a marked crisis and uncertain future or overlap with the role of the United Nations, from humanitarian to the guarantor of world security.

In fact, according to Nadkarni (2013), the plurality of national interests hinders the ability or ability of a state to assert its leadership, especially in matters related to or involving the concept of sovereignty, being the particular case here of BRICS, in areas where the freedomsecurity binomial comes into play, along with the degree of democratization of the state in question. Another aspect is the combination of a second binomial, that of environmental protection and economic development, being chosen in the name of development rather than the choice of pro-environmental policies, calling into question the climate, public health, agricultural productivity, in other words, an entire ecosystem.

According to Noonan (2013), BRICS, as emerging economies, has managed to capture the attention of international relations, on the one hand, because China has been considered the next prominent global superpower, by its economic growth and population index, and, on the other hand, India has the possibility of assuming the status of superpower, beyond its economic capacity, by having a population formed and technically sophisticated.

\subsection{A New Role for the United States and Russia?}

The United States, in order to maintain its status quo, must imperatively correct and readjust its foreign policy, redefine its place in the world, taking into account the emergence of other actors and the relational complexity in a globalized world. At this point, it may be an indicator of Donald Trump's difficulties, his inexperience in conducting state affairs, and particularly a country of the size of the United States in a global context without historical parallel, plunged into successive crises, international conflicts, terrorism, the possibility of wars, 
including the possibility of nuclear recourse, the instability of the Middle East and the Korean Peninsula.

Therefore, if the BRICS have domestic problems to solve and whose incapacity translates abroad, the same tends to happen with the leadership of the Trump administration that in effect contributes to the solubility in the own territory with worldwide effects. This kind of American exceptionalism uncovers the possibility of favouring among the BRICS the role of China in its involvement in rebalancing the balance of power in both the Korean Peninsula crisis and in the United Nations Security Council, transforming it into a strategic ally in that region, beyond Japan.

In relation to Russia, the scenario is revealed by its different and divergent nature, going back to the periods of Cold War and Pacific Coexistence, in which the Soviet ideological ghost continues to exist in the American people. The alternation of power between Vladimir Putin (President from 2000 to 20008, Prime Minister from 2008 to 2012 and, again President from 2012) and Dmitri Medvedev (President from 2008 to 2012), has hindered the modernization of the economy, the reform of the judicial system, despite the fact that at this presidential stage of Putin's stated intention to implement the ambitious plan to increase Russian competitiveness, the biggest obstacle to overcome is obviously the change in its image both in Europe the United States.

As Oliker (2016) points out, the adoption of the New National Strategy for Security, December 31, 2015 - following the New Military Doctrine (December 25, 2014), which considered Ukraine a strategic enemy, the United States and NATO as the biggest threats, highlights cooperation with the BRICS, SCO, and OSCE (Organization for Security and Cooperation in Europe) - expresses Russia's position in increasing its role and role in solving the main international problems. The same document reiterates the interest in enhancing the prestige and competitiveness of the Russian Federation, together with its participation in the multilateral framework in international, regional organizations, respecting the mechanisms of international law, not excluding its position on the EU.

This strategy focuses on Russia itself, from issues related to national defence, security, the quality of life of Russian citizens, economic growth, science and technology, education, health, culture, ecology and the environment. In this document, reference is made to the traditional Russian moral and spiritual values contextualized in a kind of "rebirth", because 
Russia needs development, strengthening and, above all, protection against foreign values that may negatively influence the country. By the way, these threats all come from either the West or from terrorists and/or extremists, hence appealing to Russian unity and morality as well as to traditional values of ethnic and religious tolerance.

In this context, the Foreign Policy Concept of the Russian Federation is approved November 30, 2016, providing a systemic vision of the main principles in this area, incorporating the national interest and the national priorities, translated into the following strategic vectors to transform Moscow into a decisive factor in international politics for using foreign policy as an instrument for creating in Russia society the image of the state as an international power: (1) to maintain its zone of influence, the Eurasian Economic Union, the post-Soviet area, particularly Moldova and Ukraine, to implement pro-European policies; (2) seek to strengthen their investment and cooperation with countries in the Asian region; (3) to form allies in the European Union in order to gain influence in policies such as the lifting of sanctions; (4) use the tools of public diplomacy (Noya, 2007) as the media to influence international public opinion; (5) to combat terrorism, notably the Daesh and to cooperate to improve its negotiating position vis-à-vis the Middle East, opposing any externally imposed leadership changes in Syria; (6) participate in international outside, BRICS, Shanghai Cooperation Organization (SCO), ASEAN, RIC (Russia, India and China).

It is precisely in Kupchan's (2012) perspective for the International Community and, in particular, the United States that the central issue is not only to assume or assist the BRICS but also to the serious domestic problems that the European Union faces without having a leadership harmonized and there is an inability to present any kind of global role. The United States is divided domestically, showing by the Trump administration an apparent difficulty; one reads the inability to maintain a coherent foreign policy in the medium / long term, as it had been with previous ones in troubled times.

\subsection{The Geopolitical Repositioning of BRICS}

It should be recalled that the concept of BRIC came from the creation of an investment bank in a given historical context, following the 9/11 terrorist attacks, the 2003 Iraq War and the need to obtain alternative markets outside "traditional" areas. However, assuming a position of acting in the name of a 'pre-emptive war', it would indicate that the United States would not hesitate to resort to the use of force against third countries in the event of a conflict of interests. 
That sentiment eventually dissipated with the Obama administration, however, under Trump, this spectre seems to come in the form of not "pre-emptive war" but in an atmosphere of uncertainties in a post-truth era.

Laidi (2011) argues that this new BRICS alliance, despite heterogeneity or divergence in international politics, crystallizes its politics by using its multiculturalism, multi-ethnicity and religious diversity, sharing common economic values and geo similarities -historical, in pursuit of its orientations of the democratization of the international system demanding in the global arena its place in counterpoint to the United States. This author assumes that the BRICS represent the product of globalization and the 2003 Iraq War resulting from the Bush Doctrine of Preventive War, corresponding to two confluent dynamics in the economic and strategic sectors.

However, in the opinion of the Ambassador and Director General of the Department of International Economic Affairs of the Ministry of Foreign Affairs of China, Zhang Jun (2014), BRICS can be considered as a new paradigm of intergovernmental cooperation with openness in the name of inclusion and contributes to common development in promoting democracy in international relations.

In this sphere, the BRICS have committed themselves to the common good of the world, believing that stability and saving the global market should be guaranteed through policies that can contribute to the improvement of government coordination in the implementation of macroeconomic policies with countries third countries to safeguard international financial stability by helping countries in difficulty who are unable to get out of the way they are. Thus, the commitment of the BRICS to the process of reform in the framework of global economic governance is firmly established, with the Development Bank as well as the World Bank and the IMF undergoing a reform of its institutions under the motivation of this group.

In a long-term scenario, the United States should learn to share power with the BRICS, namely India and China, and to do this it must implement a new strategy on its agenda in international relations based on support in the innovation sector. Leads to the acquisition of new products and the contracting of services in the context of the global market. For Schaefer and Poffenbarger (2014), what determines the continuity or stagnation of relations with the BRICS will be the variables that integrate the options of US foreign policy.

In a strategic perspective, the fact that bilateral relations prevail ensures and prevents, for example, China from strengthening or strengthening relations with Russia, since this type of 
linkage could to some extent counteract the exercise of influence or the extension of the US sphere of influence both in international relations and within international organizations, in particular, the UN.

In the Indian context, for the USA, this constitutes the pivot for Asia given its strategic location and equilibrium behaviour in its relations of proximity, especially the Chinese case. It is noted that Sino-Indian bilateral tensions result from border disputes and Indian support strategy for Pakistan and are therefore unlikely to form an alliance that would be negative for the US because it denies a potential partner in the region.

Thus, for Schaefer and Poffenbarger (2014), the BRICS aims at stopping the American race to global hegemony and exerting its influence as unipolar power because it represents a challenge and an alert to make decisions in an isolated way without the support of international organizations such as the United Nations. Remembering David Mitrany (1946), cooperation for the common good would be the objective to pursue both in obtaining and guaranteeing peace when translated into an improvement of living conditions; hence it is relevant to consider this position, considering that one should not act in crisis, on the contrary, to apply an action that precisely avoids the crisis situation.

\section{European Union: a strategic player?}

\subsection{European Union Priorities}

Given the emergence of the BRICS and the political readjustment on the part of the United States on the agenda of international politics, given the moment of exceptional state that live under the leadership of Trump, where the improbable tends to happen, the future position of the EU , according to Gratius (2013) will depend on its ability to present itself in international relations as an integrated space, of attraction to immigrants similar to the times of yesteryear, where opportunity was sought and a dream was realized, as well as giving continuity to future partnerships and alliances with the world's largest power.

The EU lacked the capacity to resolve the Syrian crisis in its Mediterranean waters, by the number of deaths fleeing in a migratory wave towards a species of European Eldorado, representing a total, from 1 January to 5 May 2017, of 1,099 that made impossible the realization of the opportunity of a better life. For the year 2016, 5.098 human beings died in the Mediterranean Sea, drowning and disappearing, has increased exponentially compared to 2015, 
which stood at 3,784. Therefore, in view of the continuity of the migratory wave, translated in these numbers that devastate our coasts and, especially, taking into account that 44,791 , only for this beginning of 2017, until May 4, risked their life towards Europe.

On Syria, the 6-year war has caused an estimated 13.5 million people to be in need of humanitarian assistance, with 4.8 million opting to go to Turkey, Lebanon, Jordan, Egypt and Iraq internally in Syria. Displaced persons reached 6.6 million, with 1 million asylums being sought on European territory, with Germany and Sweden being the preferred host countries.

It is clear that the inability to resolve this scourge puts the EU in the imperative of historically regaining its place in the international arena, notably as an interdependent global player. The domestic decline and its contribution to the aggravation of the wave of European discontent among the member states, not only by Brexit, but also in the question of assuming that these new times contain distinct ideological contours where the parties in the governing framework do not correspond from everything to the reality lived, magnifies the distance of civil society from the centre of decision-making, Brussels and its technocratic institutions.

This departure reflects another decline, that of external relations, because of the EU's inability to respond with a single voice in international politics, generating in the diplomatic field equal domestic tensions. As a result, the implementation of strategic partnerships with third countries is one of the priorities of European foreign policy, as it allows the inclusion of "new" powers, mentioned by Gratius (2013), China, Russia, Brazil, Mexico, South Korea and South Africa.

At the time, the High Representative of the Union for Foreign Affairs and Security Policy, Catherine Ashton, identified the picture of strategic partnerships as a key element of the EU's positioning on a global scale, dividing them into three groups: (1) historical partners, including Canada, Japan and the United States; (2) countries with close ideas, Mexico and South Korea; and, finally, (3) potential rivals, the BRICS. Derived from the weight in terms of power, influence and economic interdependence in the international arena, China, Russia and the United States consist of the most important and relevant partners.

\subsection{The importance of strategic partnerships}

Today, with the effect of maintaining not only the regional balance to deal with new crises, from terrorism to successive migratory waves as a result of the war in Syria and the instability on two sides, Africa and the Middle East, the EU responds through of the 
implementation of a multi-vector foreign policy that faces a double challenge: on the one hand, strengthening pragmatism and, on the other hand, guaranteeing the stability of the continuous process of regional and international integration.

Of all the threats made by the EU, those that represent and translate the greatest degree of vulnerability are terrorism and cyber-attacks, leading to increased cybersecurity due to hacking and especially espionage, which radicalization of this time, as well as the concern about organized crime, with some 3600 organizations active in European territory, involving criminal activities ranging from drug trafficking to financial and human consequences.

Consequently, according to Howorth (2016), the world is in fact in the transitional period. One of the critical points is the whole process of interaction between the EU and the United States beyond its relations with the BRICS. In this particular case, Howorth (2016) argues that in the framework of strategic partnerships between the EU and the People's Republic of China, despite the multiplicity of summits, the desired promotion between the two countries has not been achieved, namely to take the EU as a player strategy on the Asian chessboard complex. In relation to India, derived from the same situation as in China, the United States ended up holding a strategic position in terms of the alliance. As for Russia, successive crises, notably that of Georgia and Ukraine, have shown that the EU does not have the objective capacity to manage relations with one of the world's major powers so that it has chosen to act in terms of zero-sum.

In times of crisis, instability and insecurity, the strengthening of strategic partnerships that allow the EU to accept the BRICS as a whole, without necessarily considering them as rivals in the permanent struggle of its position in the international arena, despite the numerous difficulties of negotiation in sensitive points such as Human Rights, arms, migration, and terrorism.

Accordingly, the High Representative of the Union for Foreign Affairs and Security Policy, Federica Mogherini, in 2016 presented to the European Council the Global Strategy for Foreign Policy and Security of the European Union under the motto "Shared Vision: Joint Vision: A Stronger Europe". Mogherini presents a document that prompts the opening of an idealistic path in an attempt to reconnect European citizens in the sharing of common values, of identities in the name of democracy and security, with Europe under constant threat of terrorism.

If, on the one hand, one feels the desire to return to the origins of the European project through idealism, on the other hand, when applying the domestic and external policies emanating 
from each of the member states, the realism emanating from the policies in the defence and pursuit of the national interest in five priority areas: (1) the development of resilience and an integrated approach to conflicts and crises; (2) security and defence; (3) strengthening the linkage between domestic and external policies; (4) the preparation of current and future regional strategies; (5) intensification of public, climatic, energy, economic and cultural diplomacy.

In the opinion of Quiliconi and Kingah (2016, pp. 243-253), the BRICS being a unit not yet tested, it has gained its global influence and through interregional ramifications to the EU, based on a polycentric world order logic. Therefore, it considers that the implications for the EU in the relationship with the BRICS arise from delicate and sensitive issues arising from the political options of these regional powers, which share their own characteristics, but the danger derives from the homogenization or simplification of common aspects. emerge the feeling of frustration with the status quo and willingness to act to counter it.

Indeed, leadership does not inevitably translate into "good" or "benevolent", the main strategic vectors being used to capture the leadership of the BRICS from the definition of the security and economic dimensions, which will not always tend to converge with the guidelines policies.

According to Quiliconi and Kingah (2016, pp. 243-244), if we analyse the challenges faced by the BRICS and the bilateral relationship with the United States and the EU, this group, from the perspective of Noya (2007) of public diplomacy manages to sell not only an alternative image but also the possibility of benefiting from the Western-style capitalist model, even if they are not natural partners, in the role of promoting the agenda of a reform of the multilateral regime increasingly recognized by the powers traditional.

\section{Conclusion: the Limits of Change and Future Direction of the Study}

\subsection{Results from the analysis}

Indeed, of the analysis carried out in the present study reveals results indicating that there is a positive, not a transformation of the international order by the BRICS, but an increase and emergence of other poles, centres of political decision, although limited, that they wish to counterbalance with the United States and affirm solidarity in a South-South relational logic in opposition to the current neoliberal reality. 
It should be noted that since the 1960s, emerging powers have embarked on a path of subordination to the international order, while the United States has promoted the integration of a liberal international order into a world of in the confrontation with the Soviet Union. To this end, the promotion of international organizations, the opening up to free trade and the search for new investments were used. Politically, alongside the role of the United Nations, this meant, on the one hand supporting the independence of ex-colonies and the increase of nationalist movements, on the other hand, the two superpowers, USA and USSR, ended up supporting these policies of independence, each exercising its ideological degree of influence over the future independent sovereign states (Kiely, 2015).

Independence had been achieved, however, as a result of the growing complexity and the process of globalization, a new form of subordination, of hierarchizing of powers and of dependence in the world economy is promoted, which ironically accentuates inequality in a dominated world by the Western economies, that is, this new South remains dependent on the established powers and the Eurocentric vision of world reality.

It is not contradictory, but the United States, to a certain extent, is also faced with an economy dependent on foreign capital inflows, hence the policies adopted to limit the entry of foreigners and not only, in the name of internal security, Trump administration is contributing to the predictability of economic and financial difficulties, particularly in the recruitment of highly skilled labour from high tech companies from India, China, Singapore, and Malaysia. However, in terms of return on investment, US capital overseas is higher than the foreign capital invested in its territory.

The result is the emergence of a global south that has in a way ended up contributing not specifically to a system change but rather to gradually defying the current international order. To this end, China has an irreverent role, so that the political agenda of the previous US administration led by then-President Barack Obama includes Joseph Nye's concept of smart power (2011), in the combination of soft power and hard power in Sino-US relations in pursuit of: (1) strengthening the diplomatic framework in both countries; (2) of the commitment in the energy sector and concerning measures to be taken as a result of climate change; (3) setting up a task force to promote technological change; (4) to implement a joint task force on behalf of the Strategic Economic Dialogue. 


\subsection{Future issues and prospective analysis}

The rise of emerging powers has become a vital issue when two members of the group are Russia and China, in a world where there is the intention of change, the emergence of new powers, continuous financial crises, according to Piketty (2014) ) of increasing inequality and human misery in the metamorphosis of capital, of the terrorist threat, of the possibility of cyberwar, even of influencing through cyberspace and espionage the conduct of the electoral process, which may have an impact on the final result, apparently This is the case of the recent US elections and, lastly, the emergence of serious environmental crises.

All this generates instability in the international environment between changes and transformations of the international order. Thus, Gilpin (1981) argued that from a realistic perspective it would be possible to understand the systemic changes according to patterns of cyclical behaviour, so we would understand the insertion of the BRICS as a group, assuming that the distribution power has undergone a transformation has weakened the foundations of the existing system.

The United States has subjected China to intense pressure to gradually change its ideological field in order to evolve into the legacy of Deng Xiaoping, "one country, two systems," yet the seat of power, if the Communist Party of China (CCP) is to a certain extent avoiding such a goal in order to prevent the collapse of the regime, the government structure and the People's Liberation Army (PLA), by opting to monitor the evolution of time with characteristics. In this regard, for China, the BRICS symbolize the means to implement foreign policy on behalf of the New Silk Road of President Xi Jinping, by the use of a common international policy. The New Silk Road, officially announced in 2013, will connect mainland China with its neighbours in Central Asia, the Middle East and Europe to boost trade in new corridors, one by land and one by sea across the Indian Ocean and Africa to Europe as a new stimulus for its economy, which will also meet China's energy needs, with new pipelines in Central Asia and ports in South Asia, and for strategic and geopolitical purposes, will form a sanitary cordon of regional stability. (Loesekrug-Pietri, 2015). Power depends on the context of the transnational relations to which it applies, from drug trafficking, climate change, terrorism, in other words, this power becomes diffused insofar as it is chaotically distributed (Nye, 2011).

In addition to the military solution, it matters in the realistic liberal perspective of developing the great strategy in combining hard and soft power which contributes to ensuring 
security in a world plagued by conflicts and unpredictable terrorist attacks, as well as encouraging respect for the rights Human rights and the promotion of democracy in line with the principle advocated by John F. Kennedy "making the world safe for diversity".

\section{Conclusion: EU between unity and challenge}

\subsection{Limits of the research}

Taking into account the inconstancy of the present world and of international relations in the dynamics between the various actors, one of the limits in the present analysis on this subject is precisely the complexity of the current world reality, namely the speed of events and internal events that occur and the how they are transmitted by the media in which false news sometimes comes. Thus, in future terms, it would be interesting from this study to include the new actor that constitutes the cyberspace in a digital age and the impact of social media, Shahid \& Sumbul (2017) taking into account that tools such as social networks, such as the different sites on the Internet on the one hand form which is ultimately positive aspects, on the other hand, show a high risk of side. Risk in the sense of allowing the propagation of false information in an immediate time with the possibility of misleading civil society and above all provoking frictions in relations between states, companies and governments, including being able to influence internal elections. It should, as analyzed by Islam \& Zaheer (2016) be noted that we actually live in a digital age where practically all lives are gradually in a high degree of dependency, sometimes for reasons of professional necessity or for reasons resulting from social networks.

\subsection{New prospects for future research}

The quest for world unity in political polycentrism owes its balance to the need to avoid conflict on a global scale, similar to Cold War and Peaceful Coexistence times, where the risk of nuclear war was limited by the desire not to be the first to press the button that would deflagrate the common house of the humanity. The role of EU is vital in building common interests in the name of respect for human rights and development in order to transform the world into a reduction of conflicts and to rediscover an area of peace once again. European territory, moving away from the terrorism and the ghost of the extreme right, remembered by the atrocities committed in the III Reich of Adolf Hitler, of the daily life of the Europeans.

The strategic partnerships between the EU and the BRICS are strong indications of this clear willingness to cooperate in key sectors and areas, from energy to the promotion of culture 
in an attempt to establish a global plan for world peace and in the relief of the gap between the rich and the poor, of the abundance of human misery, towards a more just redistribution of resources.

It is important to point out that the idea of unity, reconstruction and economic development was underpinned by the idea of building the EU following the devastation on European territory of World War II to ensure an environment of peace and security. The question of unity relates to the sphere of cooperation between the various member states and includes the guarantee of respect for national sovereignty. However, this process of construction has been removing the sense of identity, of belonging to the citizen, or of the excessive centralization and increasing tension in the measures to be taken by Brussels or by the gradual exclusion of its citizens whose future is compromised. In addition, in matters of security, although the EU has both the Common Foreign and Security Policy and its Foreign Affairs Council with its High Representative, there is a limitation on its military capabilities and the difficulty in responding as a whole or in unity, derived from the differences that end up marking the need for decisionmaking in the face of the emergence of international conflicts, necessitating the unconditional support of NATO.

According to Violante (2017), there is a delegitimization of the system and a crisis of democracy that derive from the inability of the ruling and political classes to adapt to new realities, and this class is increasingly separated from society by the absence of identification or values common. It is important to mention that a democratic government is founded by its representation; hence it is essential to proceed to the reconstruction, in the European case of the political community based on values, ethics, respect and persuasion, moving away from the feeling of individualism and selfishness. Perhaps, in this context, European political parties also require ideological change and repositioning in their social base. This change stems both from political contestation and the open path to new populism, and from living in a time marked by the consequences of the process of globalization, inequality, migratory waves and the continuing threat of terrorism.

In addition, a feeling emerges in the defence of nationalism, remember the case of the election of Trump, where he defended, among other things, "American buy American," the case of Theresa May to design her country in the name of a "Global Britain" or the Cataluña question 
in Spain, in defence of an aspiration for independence on the part of her people and the position against the central government of Mariano Rajoy and the respective King Philip VI.

\section{References}

Ashton, C. (2012). Speech on EU Foreign Policy towards the BRICS and Other Emerging Powers. Retrieved from http://eeas.europa.eu/archives/docs/images/top_stories/020212_brics.pdf

Armijo, L. E. (2007). The BRICS Countries (Brazil, Russia, India, and China) as an Analytical Category: Mirage or Insight? Asian Perspective, 31(4), 7-42.

Buzan, B. \& Lawson, G. (2015). The global transformation. History, modernity and the making of international relations. Cambridge: Cambridge University Press. https://doi.org/10.1017/CBO9781139565073

Campillo, A. (2015). Tierra de nadie. Cómo pensar (en) la sociedad global. Barcelona: Herder. Gariup, M. (2009). European Security Culture. Language, theory, policy. Farnham: Ashgate.

Gilpin, R. (1981). War and Change in World Politics. Cambridge: Cambridge University Press. https://doi.org/10.1017/CBO9780511664267

Gratius, S. (2013). The EU and its "Strategic Partnerships" with the BRICS. Konrad-AdenauerStiftung. Retrieved from http://www.kas.de/wf/doc/9922-1442-2-30.pdf

Haass, R. N. (2017). World Order 2.0. Foreign Affairs, 96(1). Retrieved from https://www.foreignaffairs.com/articles/2016-12-12/world-order-20

Howorth, J. (2016). EU Global Strategy in a Changing World: Brussels' approach to the emerging powers. Contemporary Security Policy, 37(3), 389-401. https://doi.org/10.1080/13523260.2016.1238728

Islam, J. U., Zaheer, A. (2016). Using Facebook Brand Communities to Engage Customers: A New Perspective Of Relationship Marketing. People: International Journal Of Social Sciences, 2(1), 1540-1551. http://dx.doi.org/10.20319/pijss.2016.s21.15401551

Kiely, R. (2015). The BRICs, US 'Decline' and Global Transformations. Houndmills: Palgrave Macmillan.

Kupchan, C. A. (2012). No One's World. The West, The Rising Rest, and the Coming Global Turn. New York; Oxford University Press. https://doi.org/10.1093/acprof:osobl/9780199739394.001.0001 
Laidi, Z. (2011, November). The BRICS Against the West? CERI Strategy Papers 11. Retrieved from https://spire.sciencespo.fr/hdl:/2441/eu4vqp9ompqllr09i4icocu28/resources/n11112011.pdf

Loesekrug-Pietri, A. (2015). Why Europe can't Afford to Ignore China’s New Silk Road. In

World Economic Forum. Retrieved from https://www.weforum.org/agenda/2015/11/europe-china-new-silk-road/

Moreira, A. (2016). Teoria das Relações Internacionais. Porto: Almedina.

Mogherini, F. (2016). Shared Vision, Common Action: A Stronger Europe. A Global Strategy for the European Union's Foreign And Security Policy. Retrieved from https://eeas.europa.eu/archives/docs/top_stories/pdf/eugs_review_web.pdf

Mitrany, D. (1946). A Working Peace System. London: Royal Institute of International Affairs. Nadkarni, V. \& Noonan, N. (2013). Conclusion: Global Leadership in the Twenty-First Century. Nadkarni, V. \& Noonan, N. (eds). Emerging Powers in a Comparative Perspetive. The Political and Economic Rise of the BRIC Countries (pp. 209-219). New York: Bloomsbury.

Noonan, N.C. (2013). The Global Leadership of the USA and the Emerging Powers. Nadkarni, V. \& Noonan, N.C. (eds). Emerging Powers in a Comparative Perspective. The Political and Economic Rise of the BRIC Countries (pp. 23-41). New York: Bloomsbury.

Noya, J. (2007). Diplomacia Pública para el Siglo XXI. La gestión de la Imagen Exterior y la Opinión Pública Internacional. Madrid: Ariel.

Nye, J. (2011). The Future of Power. New York: PublicAffairs.

Oliker, O. (2016). Russia's Nuclear Doctrine. What We Know, What We Don't, and What That Means. Washington: CSIS. Retrieved from https://csis-prod.s3.amazonaws.com/s3fspublic/publication/160504_Oliker_RussiasNuclearDoctrine_Web.pdf

Piketty, T. (2014). Capital in the Twenty-First Century. Cambridge: The Belknap Press of Harvard University Press. https://doi.org/10.4159/9780674369542

Quiliconi, C; Saguier, M. \& Tussie, D. (2016). BRICS: Leadership in the Making. In kingah, S.; Quiliconi, C. (eds). Global and Regional Leadership of BRICS Countries (pp. 29-46). New York: Springer. 
Schaefer, M. E. \& Poffenbarger, J. G. (2014). Formation of the BRICS and Its Implication for the United States: Emerging Together. New York: Palgrave Macmillan. https://doi.org/10.1057/9781137387943

Selim, F. (2017). Postmodern Liberalism and Solidarity: Richard Rorty. People: International Journal Of Social Sciences, 3(2), 654-671. https://dx.doi.org/10.20319/pijss.2017.32.654671

Shahid, A \& Sumbul, M. (2017). Social Evils in Media: Challenges And Solutions In 21st Century. People: International Journal Of Social Sciences, 3(3), 854-875. DOIhttps://dx.doi.org/10.20319/pijss.2017.33.854875

Violante, L. (2017). Democrazie senza memoria. Torino: Giulio Einaudi.

Zhang J. (2014). BRICS adds New Dynamism to International Relations. Ministry of Foreign Affairs of the People's Republic of China. Retrieved from http://www.fmprc.gov.cn/mfa_eng/wjbxw/t1170274.shtml 